\title{
ANALYSIS OF THE DYNAMICS OF THE EUROPEAN BANKING SYSTEM
}

\author{
Marianna Stehnei ${ }^{1}$, Maryna Korol ${ }^{2}$
}

\begin{abstract}
Relevance of research. Existence of global financial crises points to the fact that in the world there is no perfect banking system and therefore the efficiency of the banking system requires a detailed study, including major performance indicators. The aim of the study is to summarize and characterize the existing trends of banking system evolution in the European Union. Methodological basis of the study - is based on the analysis of the study of the dynamics of such indicators as the number of banking institutions, the volume of assets and liabilities, asset quality, as well as the profitability of the banking sector of the European Union. A systematic analysis of the quantitative and qualitative composition of the above-mentioned banking indicators, synthesis and generalization were used to generalize and formulate conclusions. Scientific results. This article is devoted to the study of the dynamics of the main indicators of the European banking system during the period from 2000 to 2019 inclusive. It is argued that the number of commercial banks has decreased over the last decade, including in the European Union. Bank branches are no exception, the negative dynamics of the number of which was followed by the global financial crisis of 2008-2009. At the same time, it was found that the volume of bank assets shows a positive trend. Regarding the geographical distribution of assets, in 2019 the leading position was taken by France, Germany, Italy and Spain. At the same time, the volumes of liabilities of the financial sector of the European Union for the studied period also show a positive trend. The structure of loans is characterized and it is emphasized that the vast majority of loans are issued to non-financial corporations and households, which is an evidence of the business orientation of banks to provide loans to the real sector of the economy. It has been established that one of the key problems facing European banks is profitability, which today still could be on a better level than in 2007, the year of the financial surge. This situation distances European banks from competitors in the United States, which have shown positive dynamics of their profits. However, it is encouraging that the quality of assets of the European Union banks has significantly improved over the last 4 years. The practical significance of the study is to rate the strengths and weaknesses of the European banking system. Significance/originality. The results achieved from an integrated view of the functioning of the banking system of the European Union, which will allow the authors to further build a model for verifying the stability of the banking system.
\end{abstract}

Key words: banks, European banking system, assets and liabilities of commercial banks, financial sector, distressed loans.

JEL Classification: E51, E59, G21, G34

\section{Introduction}

The key to a successful economy in any country is an efficient banking system. After all, it is well-functioning banking systems that are able to mobilize and efficiently allocate resources so that the country's "blood vessels" function effectively. As hundreds of years ago, today's bankers seek to expand their activities in all possible aspects, offering both traditional and non-traditional banking services.
The growing interest to the financial problems of the European Union can be argued by the fact that the European banking system has survived the global financial crisis, which has resulted in significant problems that need to be resolved in order to continue further effective functioning. Undoubtedly, the European banking system is extremely important in the world market economy, as its component are the central banks of the European Union.

\footnotetext{
Corresponding author:

${ }^{1}$ Mukachevo State University, Ukraine.

E-mail: stegneym@gmail.com

ORCID: https://orcid.org/0000-0002-4688-6447

${ }^{2}$ Uzhhorod National University, Ukraine.

E-mail: maryna.korol@uzhnu.edu.ua

ORCID: https://orcid.org/0000-0003-4031-0858
} 
Professor Mishkin (Mishkin, 2008) of Columbia University, who studied the impact of monetary policy on financial markets and financial institutions, made a significant contribution to the development of the theory and practice of banking systems, in particular to the study of the banking system of the European Union.

We share the views of scientists who argue that the European banking markets have become increasingly integrated in recent years, but obstacles to full integration, especially in retail, still remain. European integration can have consequences for systemic risk and can create various challenges for the current supervisory system. It affects competition in banking markets, the nature of long-term borrower-lender relations, as well as the links between ownership structure, technological change and bank efficiency (Goddard, Molyneux, Wilson \& Tavakoli, 2007).

In his work, Dermine J. (Dermine, 2006) confirms the progress of the European banking integration over the past twenty years and rates the current system of banking supervision and deposit insurance, based on the control of "countries-countries".

The statement by Altunbaş Y., Chakravarty S. (Altunbaş, Chakravarty, 1998) is of particular note, it compares the performance of European Union banks across national borders involves studying the differences between countries in the institutional structure of the banking system.

The works of the above-mentioned scientists and many other works prompted us to study the dynamics of the main indicators of the European banking system in order to further construction of a model of its stability.

\section{Quantity of banks, assets and liabilities dynamics}

The downward trend in the number of credit institutions (CIs) of the EU-28, which began in 2009, continued in 2018, although at a slower pace, their number decreased to $6,088(-2.6 \%)$ compared to 2017. One in four CIs ceased to exist after the 20082009 financial crisis.

2019 was no exception: the number of CIs in the EU decreased by $1.8 \%$ to 5,982 , of which 4,472 were CIs in the Eurozone.

Rationalization in the EU banking sector has also affected banking branches. In 2019, their number was 163,265 units, down $6 \%$ compared to 2018 . It should be noted that before the financial crisis of 2008-2009, there was a positive dynamics of the number of branches, and a negative one after it (Figure 2).

The downward trend in the number of branches continues to reflect the increasing use of internet banking by consumers, as more than half of the EU users - 54\%, used it in 2018, compared to $51 \%$ in 2017 and $25 \%$ in 2007 . The countries that experienced the largest decrease in absolute terms in 2018 were Germany $(-2,185$ units), Italy $(-1,920)$ and Spain $(-1,314)$. Only Bulgaria opened new branches (+82 units) (European Banking Federation, 2019 c, p. 11).

The assets volumes of EU banks increased in 2018, amounting to 43.35 trillion EUR, 30.9 billion EUR of which are in the Eurozone and 12.5 billion EUR in the non-Eurozone. The expansion was mainly due to the growth of total assets in the Eurozone countries (1.6\%) (European Banking Federation, $2019 \mathrm{~d}$ ).

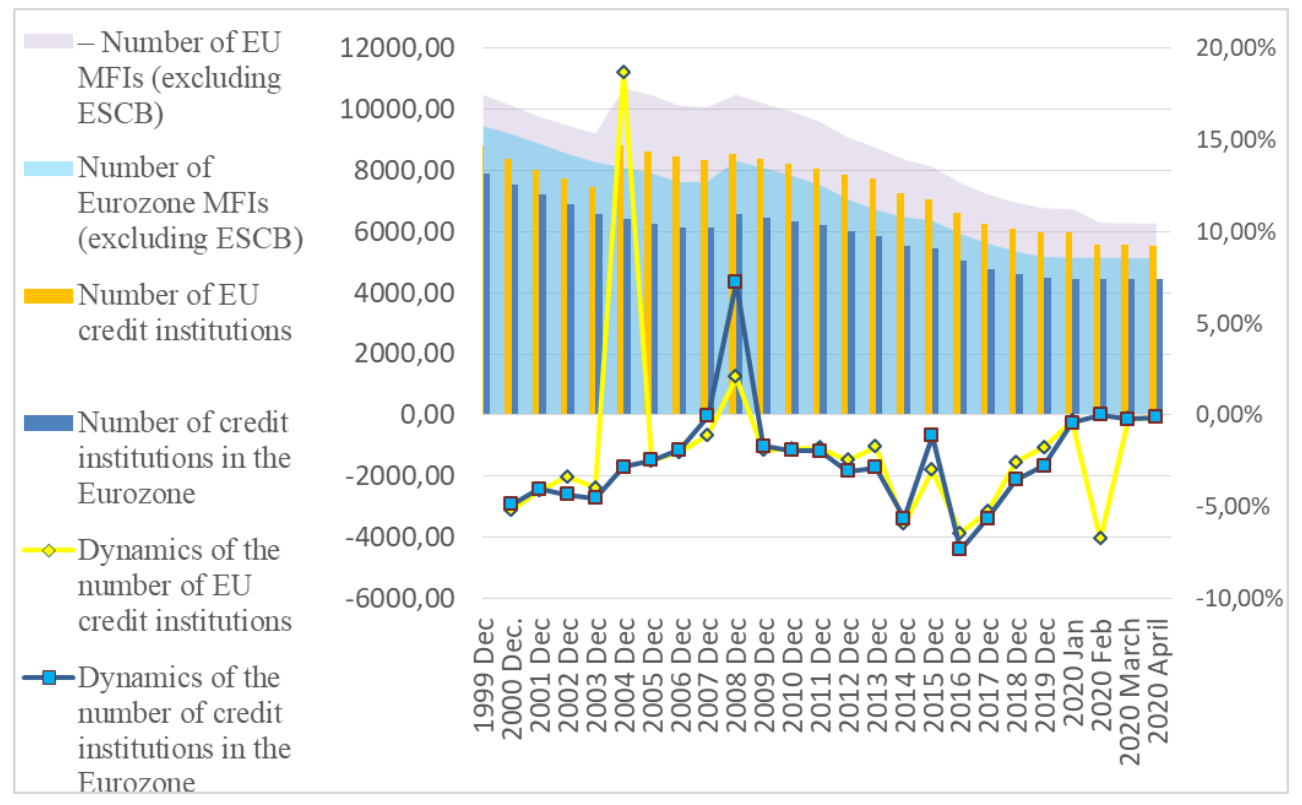

Figure 1. Number of EU credit institutions, 2000-03.2020

Source: compiled by authors based on the European central bank, 2000-03.2020 (European central bank, 2020 c) 


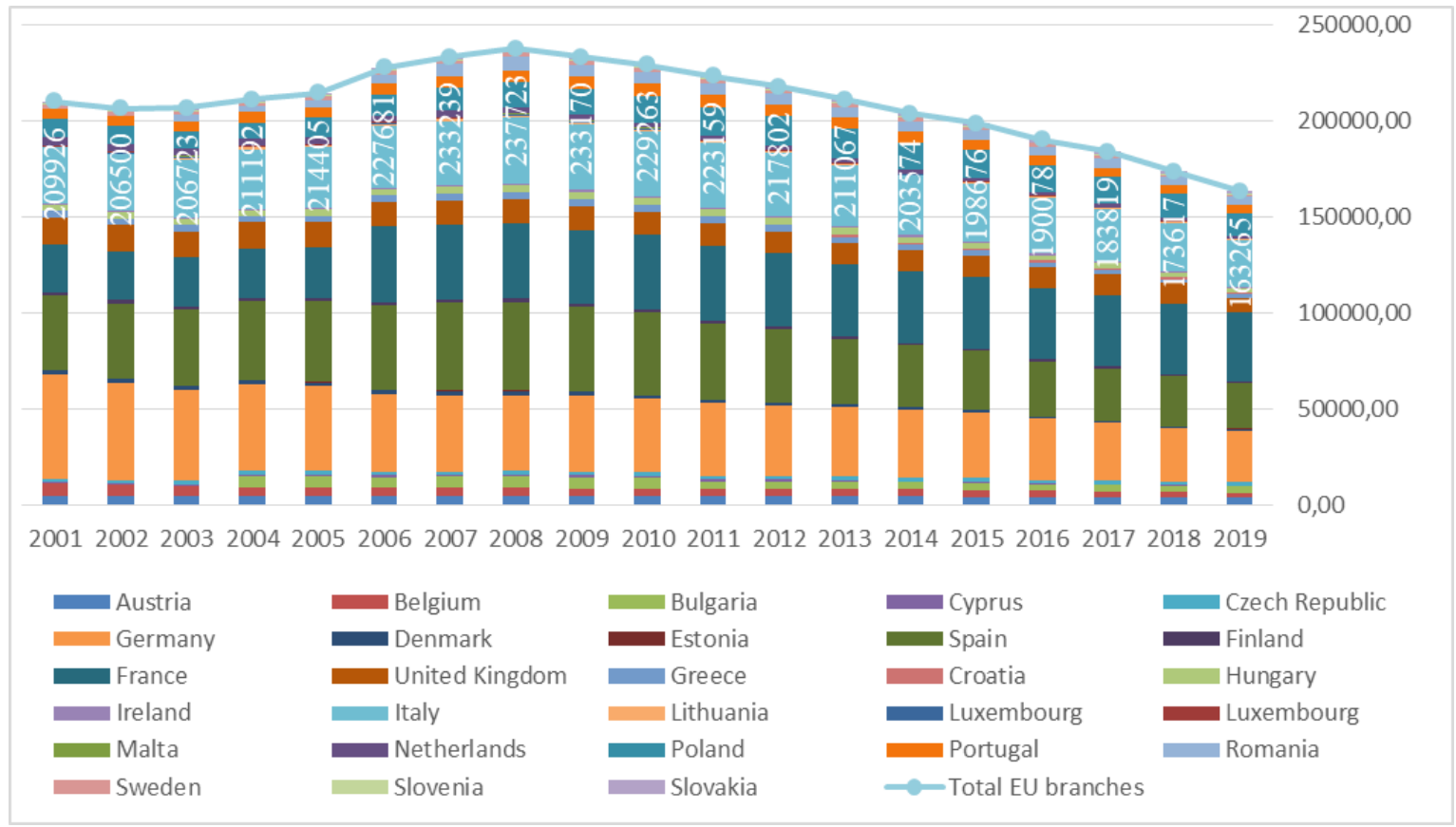

Figure 2. Dynamics of the number of branches of the European banking sector, 2001-2019

Source: compiled by authors based on the European central bank, 2000-03.2020 (European central bank, $2020 \mathrm{~m}$ )

Eurozone $\mathrm{Cl}$ assets
$\begin{aligned} & \text { Assets of MFIs of the rest of } \\ & \text { the } \mathrm{EU}\end{aligned}$
$\rightarrow$ Eurozone MFI assets

Figure 3. Assets of the banking sector, 2000-03.2020

Note: The European Banking Association (EBA) uses data on credit institutions (CIs) and Monetary Financial Institutions (MFIs) in its reports, however, the ECB does not have "pure" data on banks. As banks account for $75-80 \%$ of the entire financial system in the EU, the EBA considers it appropriate to analyze the banking sector on the basis of CI and MFI data.

Credit institution (CI) - any institution that is (i) a business entity that has deposits or funds from individuals (on terms of repayment) and provides loans, or (ii) an enterprise or any other legal entity other than those who comply with subparagraph (i) who issue means of payment in the form of electronic money.

Monetary financial institutions (MFIs) - Financial institutions that together form the sector sector which issues money to the Eurozone. These include: the Eurosystem, resident credit institutions (as defined by the EU legislation) and all other resident financial institutions whose activities are to attract deposits and / or closed substitutes for deposits from entities other than IFIs, lending and / or investment in securities (the latter group consists mainly of money market funds).

Source: compiled by authors based on the European central bank, 2000-03.2020 (European central bank $2020 \mathrm{~g}, 2020$ j, $2020 \mathrm{e}$ ) 
Thus, according to Figure 3, 2019 is no exception. The total assets of MFIs amounted to 45.52 trillion EUR, 32.4 trillion EUR of which account for MFIs in the euro area and 13.1 trillion EUR to the MFIs of other EU member states. In general, this indicator continues to show positive dynamics: the volume of total assets increased by $5 \%$.

In the geographical distribution in 2018, the highest increase was shown by Finland - 176 billion EUR (39.1\%). Among the four largest European countries, only France recorded a significant positive result in terms of assets of the banking sector, which increased by $4.2 \%$, Italy and Spain - by $1.3 \%$ and $2.9 \%$, respectively. The countries with the most significant decrease in assets were Cyprus (-13.1\%) and Latvia (-19.5\%) (European Banking Federation, 2019 d).

In 2019, among the Eurozone member states, the largest share in the total assets of the banking sector was: France - 29\% (9.32 trillion EUR), Germany - 26\% (8.31 trillion EUR), Italy - 11\% (3.72 trillion EUR) and Spain - 8\% (2.68 trillion EUR). All the abovementioned countries in 2019 showed a positive trend, the largest increase was in Germany - 7\%. Among the Eurozone countries, the largest growth occurred in Ireland - 14\% (4\% of total assets), and a decrease in Malta - 9\% ( $0,13 \%$ of assets) (European central bank, $2020 \mathrm{~g}$ ).

For the seventh year in a row, HSBC Holding PLC is the largest bank in Europe in terms of assets. At the end of 2018, the UK-based financial institution had assets totaling 2.2 trillion EUR. French BNP Paribas SA, with 2.04 trillion EUR, is the second largest bank, and another French bank, Crédit Agricole Group, ranks third with 1.9 trillion EUR. These three occupy the highest positions in the Top largest European banks in terms of assets according to S\&P Global Market Intelligence (Ali, 2020).

German flagship bank Deutsche Bank with assets of 1.6 trillion EUR fell from 4th to 5th place with assets of 1.4 trillion EUR. The Spanish company Banco Santander SA took this 4th position, but a possible merger between Deutsche and its competitor Commerzbank AG could lead to the formation of a bank with total assets of 1.8 trillion EUR, which will be the fourth largest in Europe (Ali, 2020).

Seven of Europe's 50 largest banks are headquartered in Germany, and together they have 3.1 trillion EUR in assets. In France and the United Kingdom, there are six banks in the ranking, which together have 7.6 trillion EUR and 6 trillion EUR in assets, respectively (Ali, 2020).

Regarding the total liabilities of the financial sector, as of March 2020, they amounted to 30.03 trillion, an increase over the period under review by $41.2 \%$.

The importance of bank lending is a specific characteristic of the European economy. Proof of this is the positive dynamics of loans.

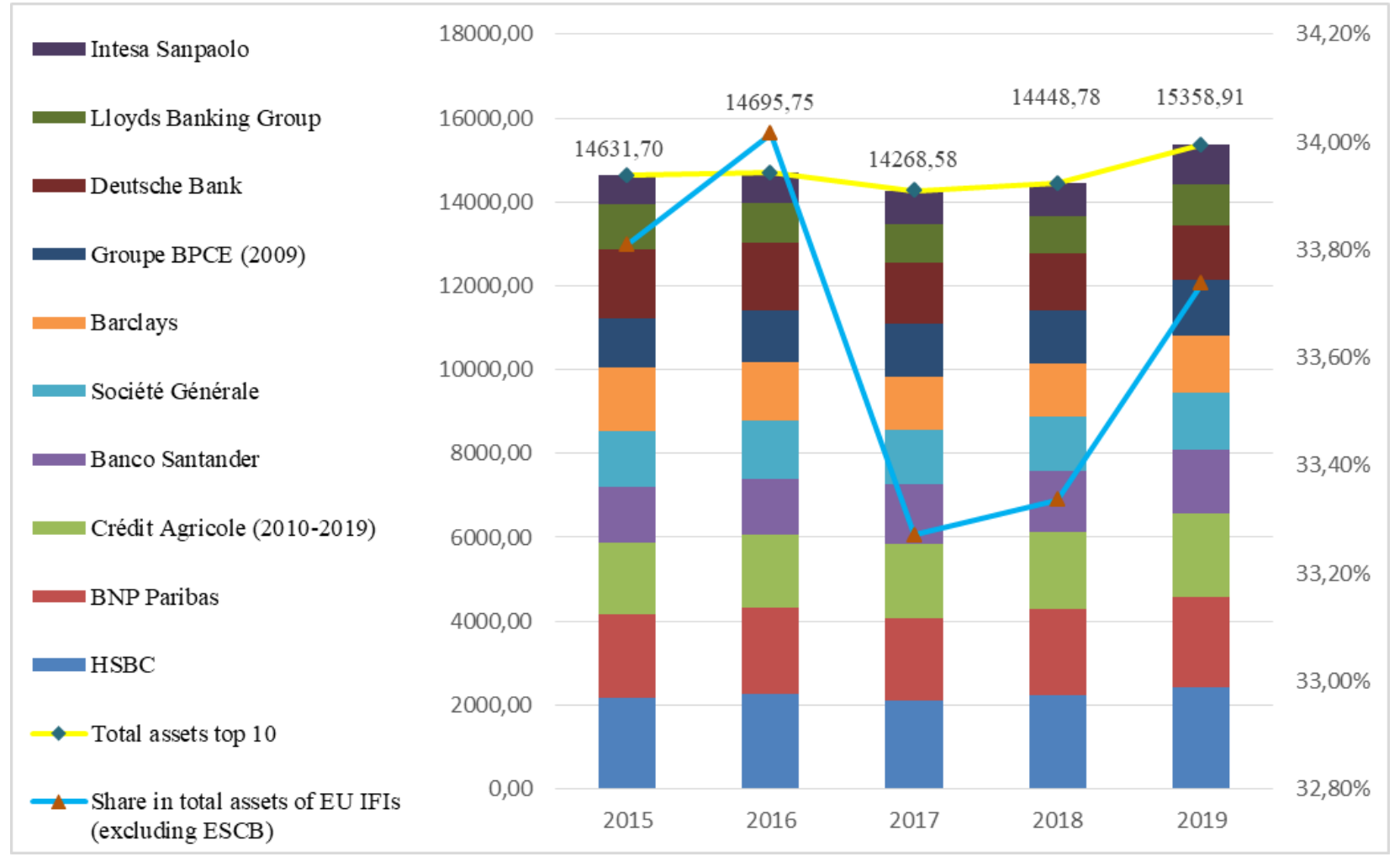

Figure 4. Top 10 EU banks with the largest assets, 2015-2019

Source: compiled by authors based on the European central bank, 2015-2019 (European central bank 2020 h, 2020f) 


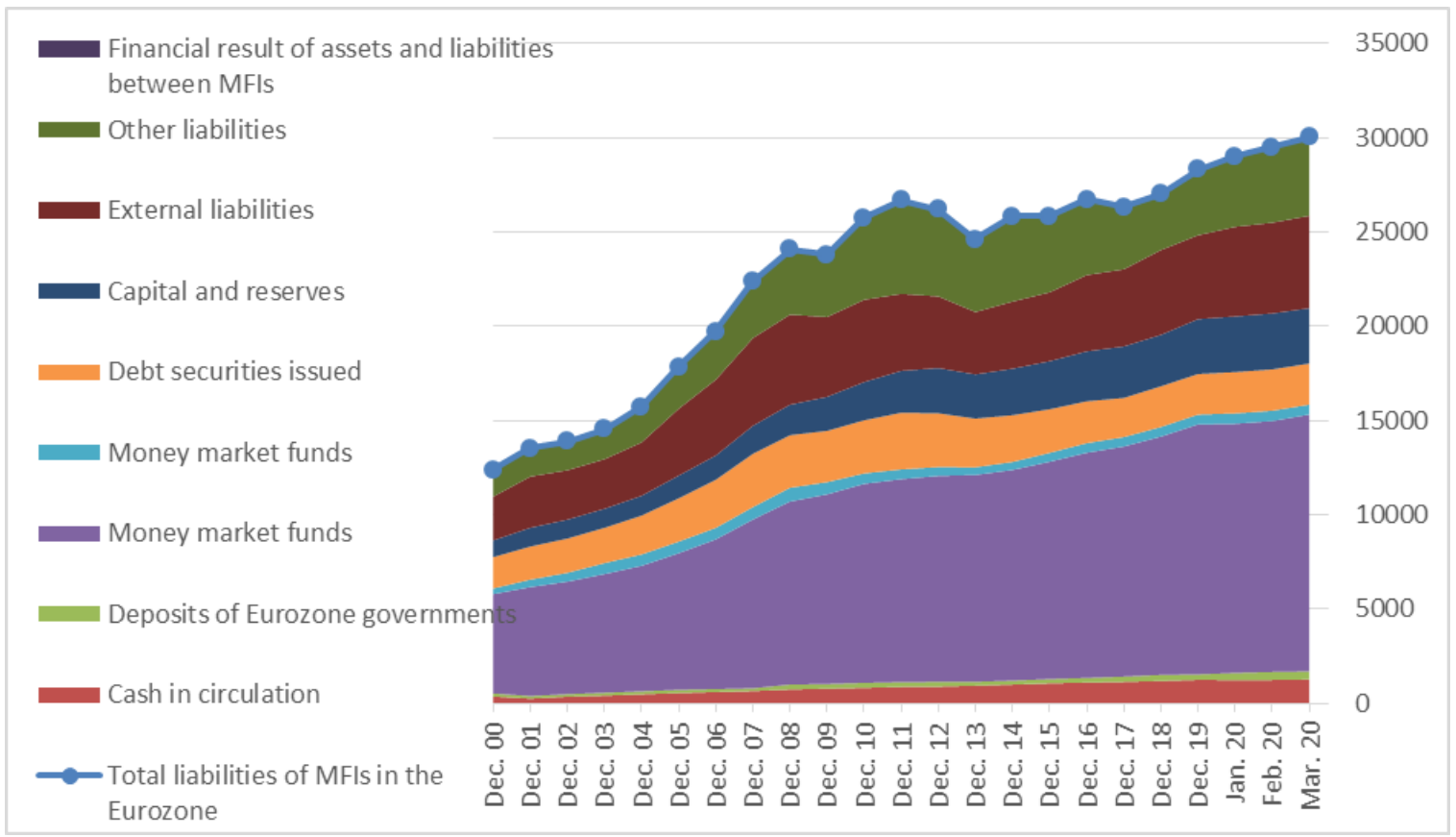

Figure 5. Structure of liabilities of Eurozone MFIs (excluding ESCB)

Source: compiled by authors based on the Oesterreichische Nationalbank, European central bank 2000-03.2020 (Oesterreichische National bank, 2020, European central bank, $2020 \mathrm{~g}$ )

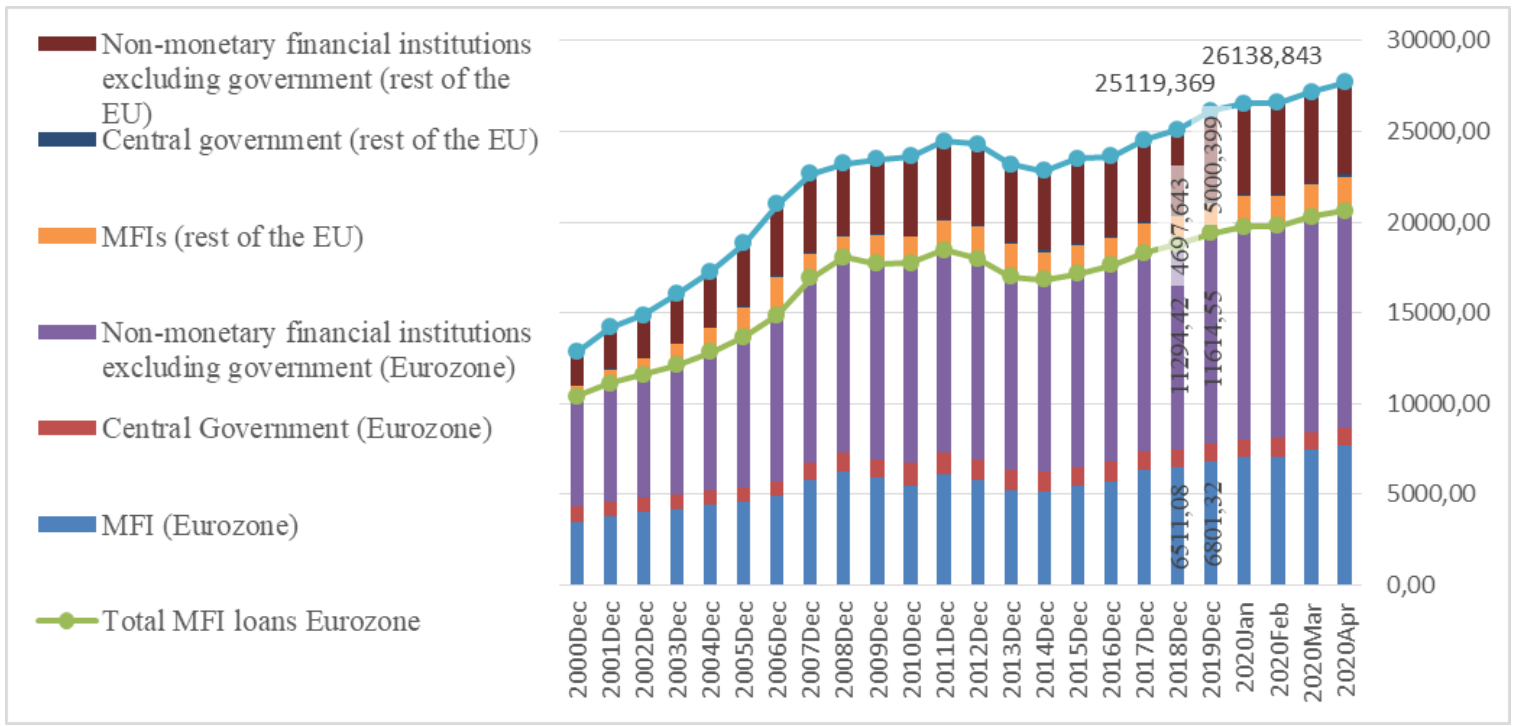

Figure 6. Structure of EU MFI loans (without ESCB)

Source: compiled by authors based on the European central bank, 2000- 04.2020 (European central bank, $2020 \mathrm{~g}$ )

Thus, the total amount of loans issued to EU MFIs increased by $2.5 \%$ in 2018 and reached more than 25.1 trillion EUR. The growth was mainly due to the growth of loans to non-financial institutions, without government loans, which increased by $3.4 \%$ in year calculations to more than 15.5 trillion EUR (European Banking Federation, 2019 c, p. 19).

Household loans in the Eurozone have been showing positive dynamics for the fourth year in a row, rising by almost 540 billion EUR since 2015. Loans to nonfinancial corporations (the non-financial corporations sector includes all private and public enterprises that produce goods or provide non-financial services) in the EU increased by $3.8 \%$ in 2018 to almost 5.5 trillion EUR (this is the highest figure since 2012) (European Banking Federation, 2019 c, p. 19).

If we talk about the structure of the credit line, it can be seen from the following figure that the vast majority 


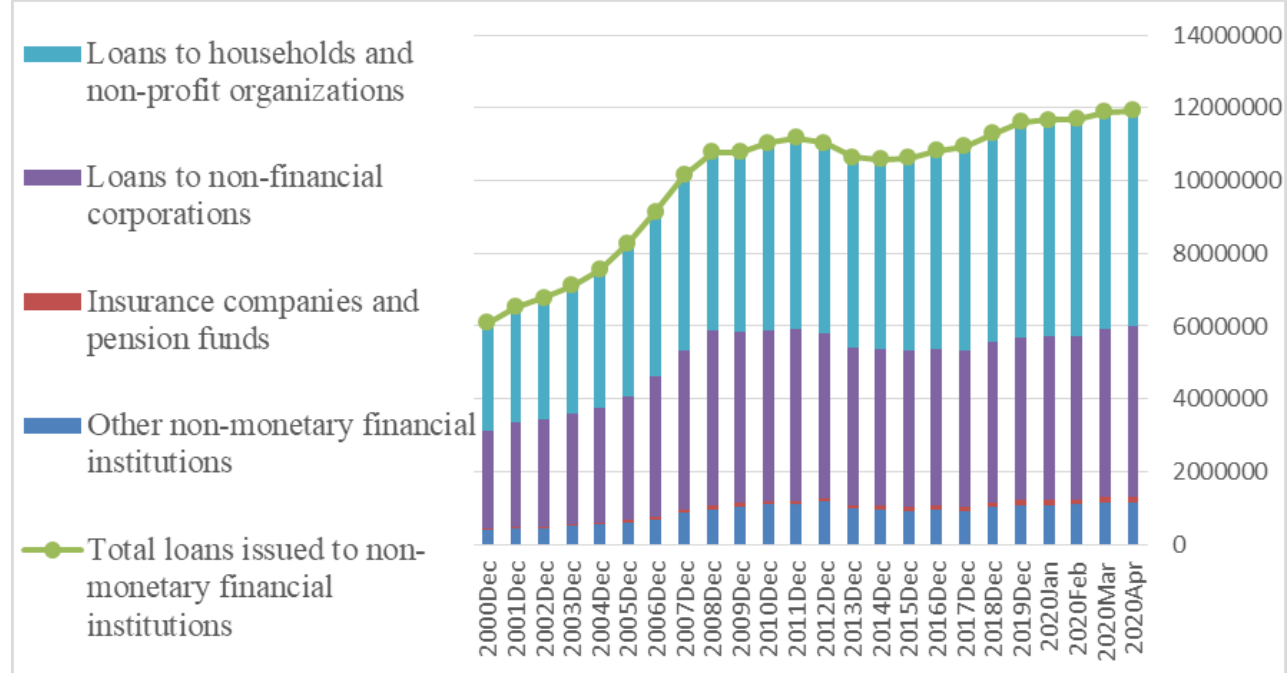

Figure 7. Structure of Eurozone MFI loans to non-monetary financial institutions

Source: compiled by authors based on the European Central Bank, 2000-04.2020 (European Central Bank, 2020 a)

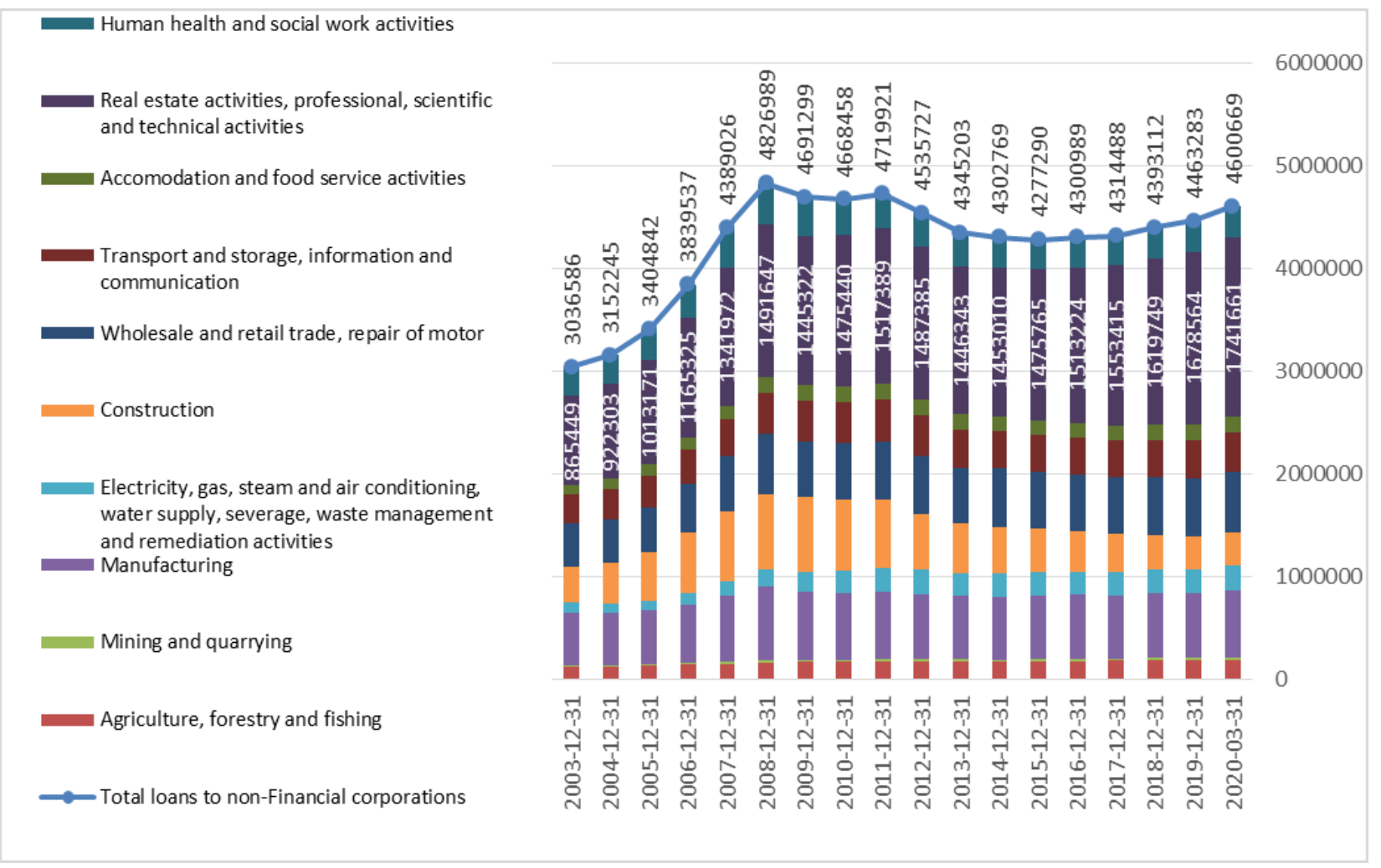

Figure 8. The structure of Eurozone MFI loans to non-financial corporations by economic sector

Source: compiled by authors based on the European Central Bank, 2003-03.2020 (European Central Bank, 2020 b)

of bank loans are issued to non-financial corporations (NFCs) and households. These figures, in particular, demonstrate the strong business orientation of banks in lending to the real economy.

Regarding the structure of loans to non-financial corporations, it should be noted that real estate activities, professional, scientific-technical and administrative and support services accounted for more than a third (36.9\%) of loans issued at the end of 2018 , and more than $30.8 \%$ in IV quarter of 2008, in 2019-37.6\%. Production, as well as wholesale and retail trade $-14.1 \%$ and $12.9 \%$, respectively (European Banking Federation, 2019 c, p. 21).

As already mentioned, the largest share in issued loans is occupied by loans to households and non-profit 


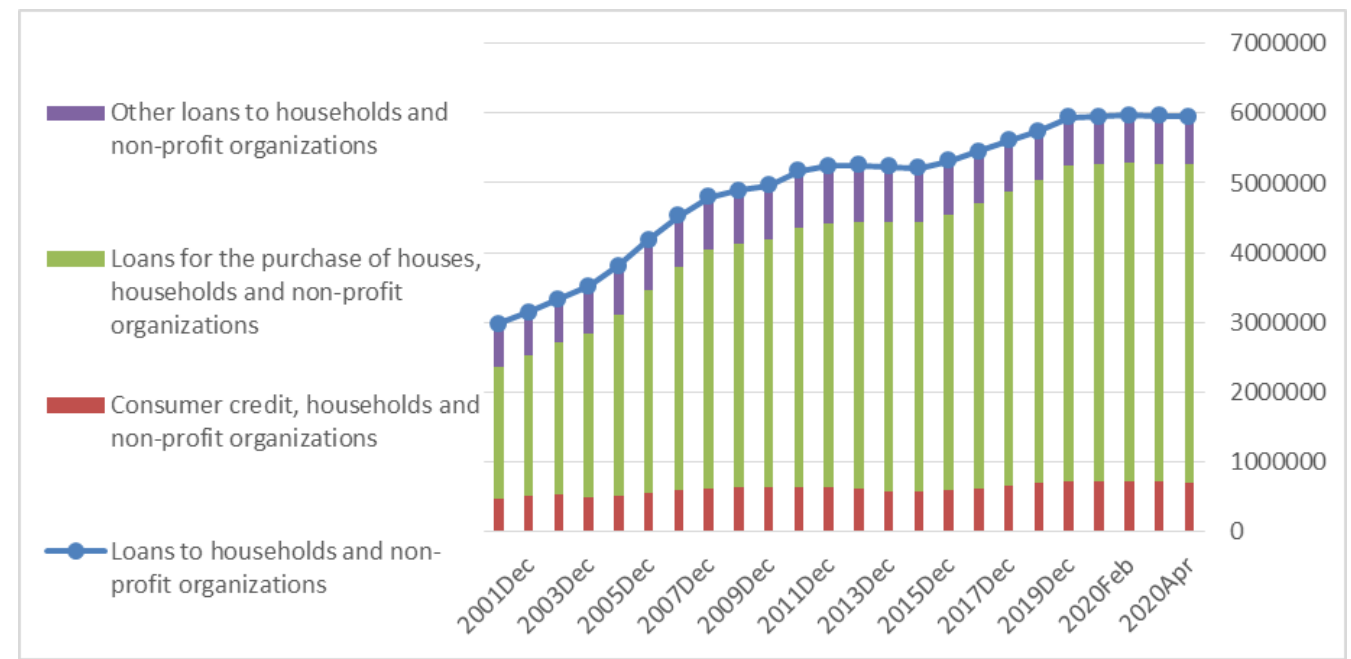

Figure 9. The structure of Eurozone MFI loans (excluding the ESCB) provided to households and non-profit institutions serving them

Source: compiled by authors based on the European Central Bank, 2001-03.2020 (European Central Bank, $2020 \mathrm{~g}$, European Central Bank, 2020 d)

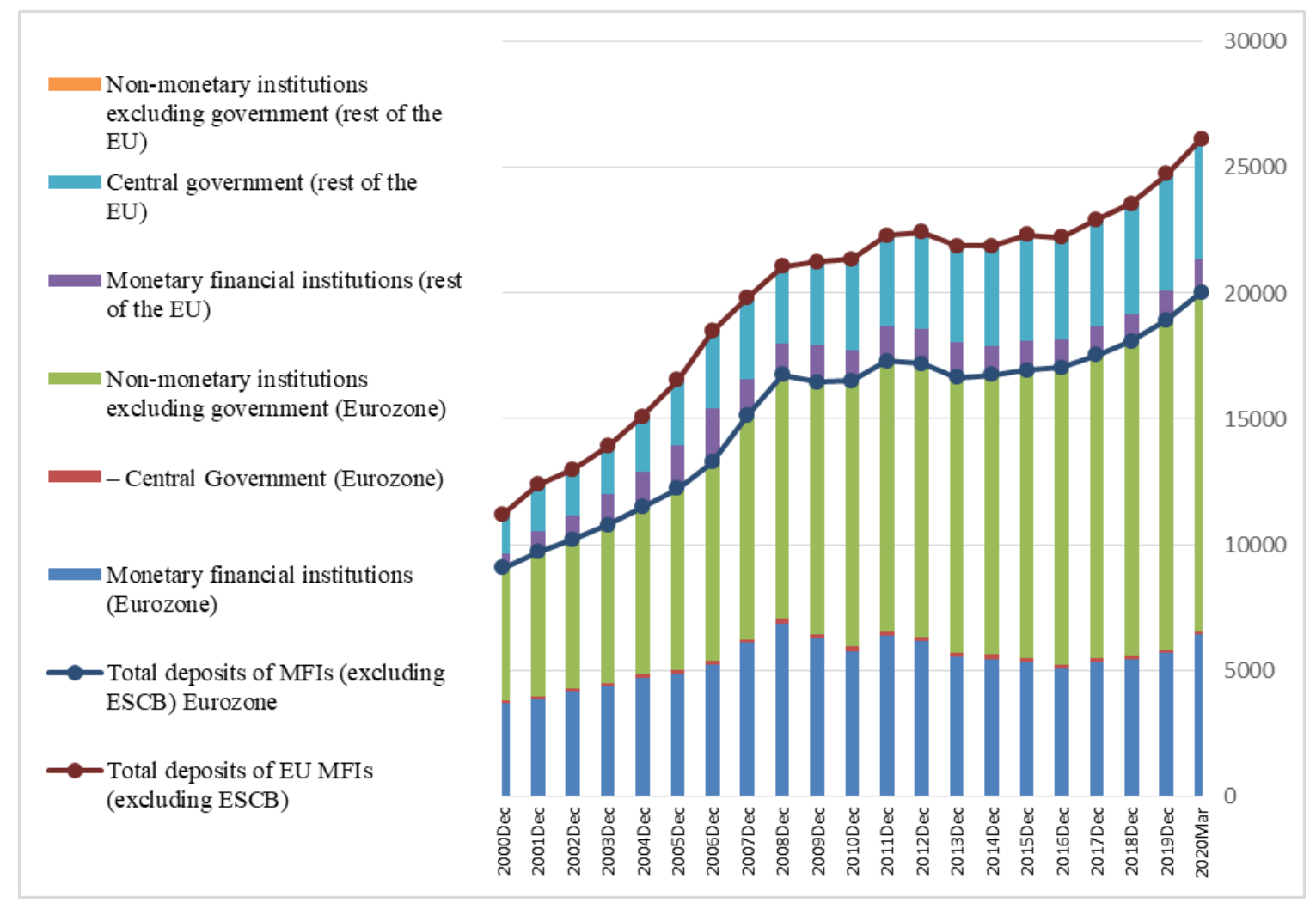

Figure 10. Structure of deposits of EU MFIs, 2001-03.2020

Source: compiled by authors based on the European Central Bank, 2000-03.2020 (European Central Bank, 2020 i, European Central Bank, 2020 k)

organizations that serve them. In 2019, this figure in the Eurozone was 5.94 trillion EUR, of which the lion's share are loans for housing 4.53 trillion EUR, which has been showing positive dynamics since 2015 .

In 2018, the amount of deposits attracted to the EU banking sector increased by $2.8 \%$ and amounted to 23.6 trillion EUR. France accounted for more than half of the increase in deposits - 346 billion EUR. MFI deposits in France in 2018 increased by almost 185 billion EUR. Deposits by non-government institutions excluding government increased by 162 billion EUR in France, 109 billion EUR in 
Germany and 113 billion EUR in the UK (European Banking Federation, 2019 c, p. 18).

\section{Profitability, quality development of loan portfolios}

One of the important indicators of the state of the banking system - the return on equity of banks $\boldsymbol{R O E}$ - a key indicator for assessing the attractiveness of the banking sector for investors. Unfortunately, the profitability of the European banks remains low, which is a consequence of the difficult economic situation in the $\mathrm{EU}$ in recent years.

In 2008 , three EU countries had a negative ROE value in the Eurozone: Belgium - 44.6\%, the Netherlands $11.9 \%$ and Germany $-11.4 \%$. In 2011 , the number of countries with a negative value of ROE banking systems doubled: Cyprus - 102.8\%, Italy - 14.3\%, Slovenia $16.9 \%$, Ireland $-15.4 \%$, Portugal $-5.4 \%$, Greece $-2.1 \%$. Of those countries that are not part of the euro area, in 2008, the negative value of ROE were in the United Kingdom $(-12.2 \%)$ and Denmark $(-5.0 \%)$ (Valverde, S., Fernández, F, 2018, pp. 19-20).

As the ECB maintains its ultra-low interest rates, profitability remains a key challenge facing European banks. The profitability of European banks in 2018 was $6.1 \%$ for the EU-28, compared to $5.8 \%$ in 2017. Although it is still far from the $10.02 \%$ registered in the outbreak of the financial crisis, it is the highest since 2007 (European Banking Federation, 2019 c, p. 27).

Probably the most common response to the difficulty of increasing profits was to reduce costs. Not surprisingly, most major European banking sectors had higher efficiencies (lower cost-to-income ratios) than at the beginning of the crisis. In 2008, Spain had the lowest cost-to-income ratio of the analyzed countries, which was also observed in the third quarter of 2017: $51.76 \%$, Spanish banks were even more efficient than Dutch banks (55.99\%) and French (71,70\%), German (71.01\%) and Italian (62.41\%) banks (Valverde, S., Fernández, F, 2018, p. 19-20).

Given that many of these countries are already experiencing intense reductions in branch numbers and staff reductions, the digitalization phenomenon may require more complex work on this front, requiring banks to maintain even lower cost-to-income ratios. Despite rising inflation, the European banks continued to face negative real interest rates. This makes it difficult to profit from the main activity of mediation, in other words, the spread between the profitability of borrowed funds and financing costs.

The banking system of the Eurozone has entered a coronavirus crisis in a weak state, and the profitability of the sector fell for the first time in three years in 2019, according to the European Central Bank's data. Thus, the slowdown in economic growth and falling interest rates resulted in the fact that the return on equity in 113 banks controlled by the ECB in 2019 decreased from $6.2 \%$ to $5.2 \%$. The least profitable banks by country were German ones, where 21 ECB-controlled banks had an average return on equity of only $0.08 \%$. This was far below the profitability of Italian banks, which are generally considered the weakest sector, with an average return on equity of $4.85 \%$ last year.

The decline in the profitability of Eurozone banks distances the European banks from their competitors in the United States, which last year reported on average return on equity more than twice as high. It is also worth noting the growing vulnerability of Europe's banking sector to the economic and financial turmoil caused by measures to contain the coronavirus pandemic, which are forcing a large number of companies and employees to seek government assistance. Credit margins in the

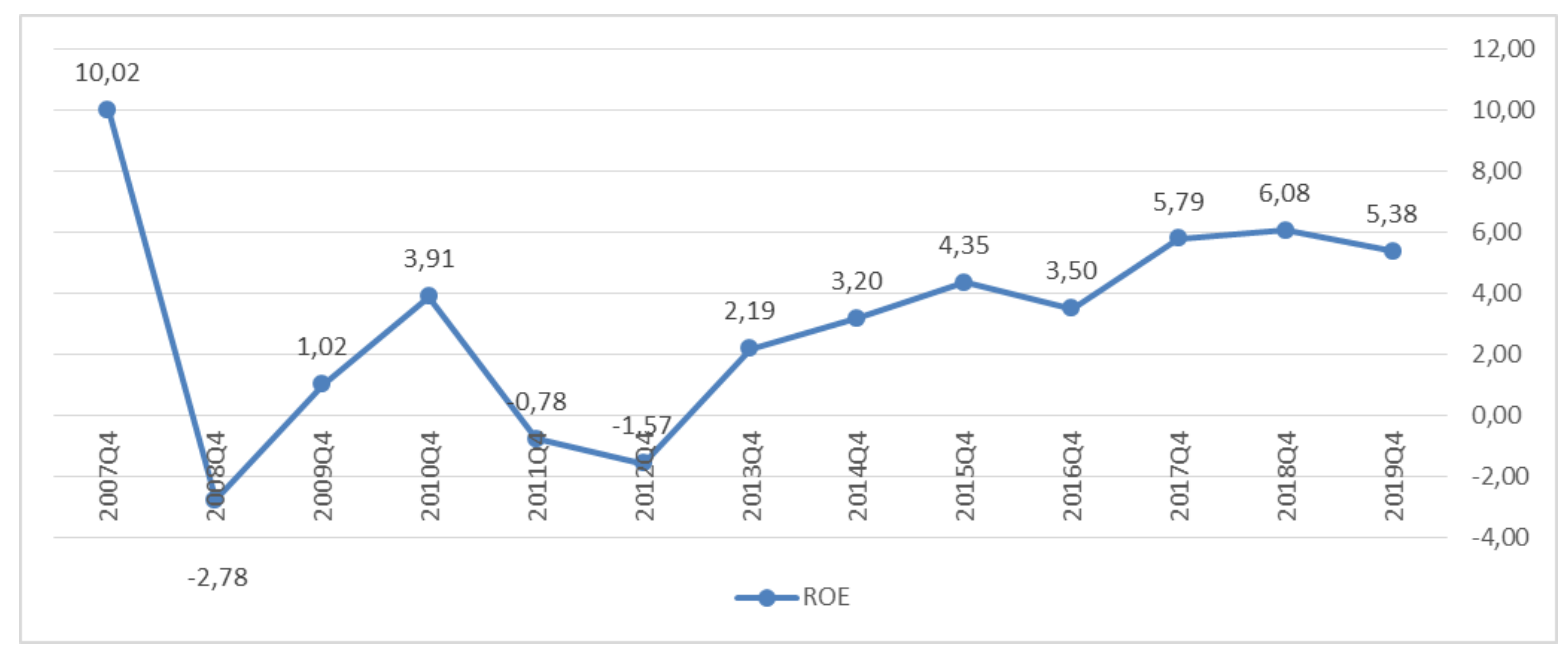

Figure 11. Dynamics of the return on equity of the EU banks, 2007-2019

Source: compiled by authors based on the European Central Bank, 2007-2019 (European Banking Federation, 2019 c) 


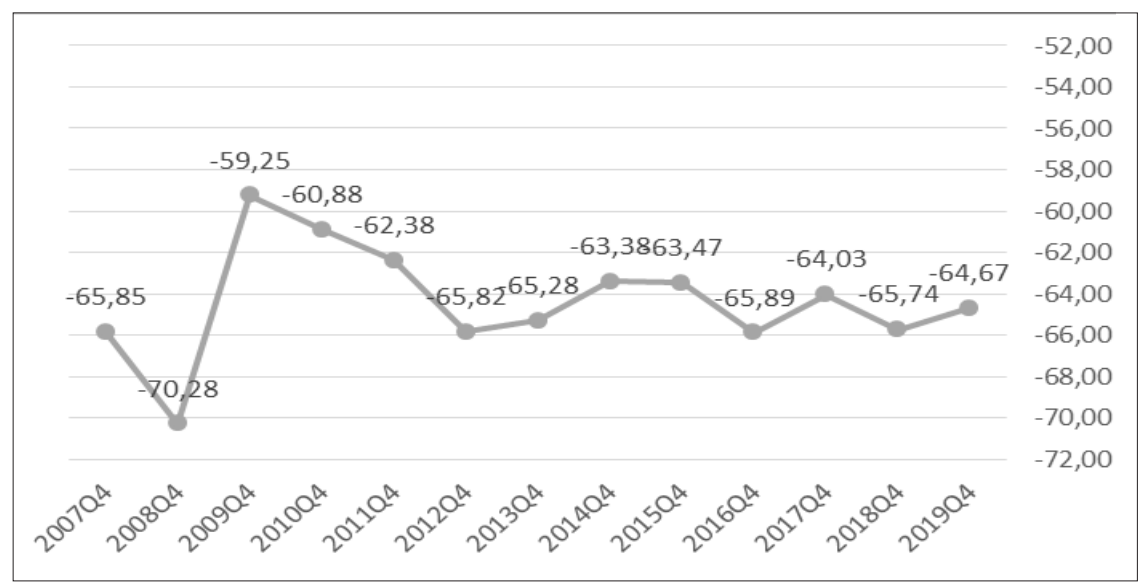

Figure 12 Cost-to-income ratio in the European banking sector, 2007-2019

Source: compiled by authors based on the European Central Bank, 2007-2019 (European Banking Federation, 2019e)

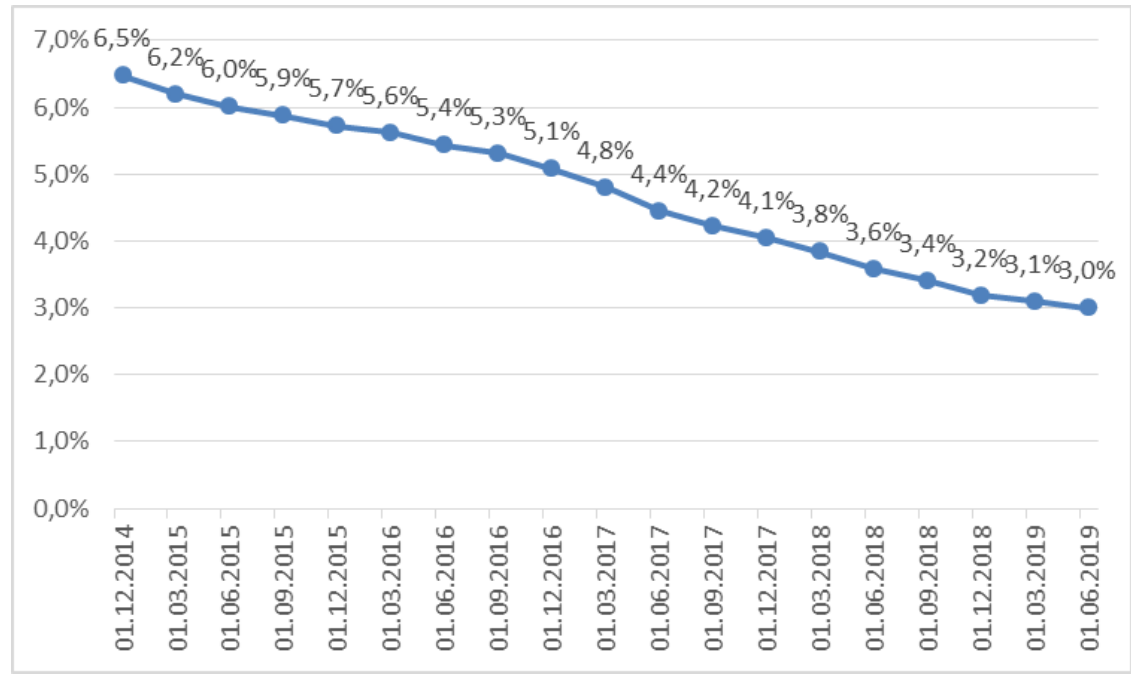

Figure 13. Weighted average ratio of non-performing loans

Source: compiled by authors based on the European Central Bank, 2014-2019 (European Banking Federation, 2019 b)

sector also declined due to lower ECB interest rates to a record low of minus $0.5 \%$. Economists predict that the Eurozone economy may shrink by about $10 \%$ in the second quarter of 2020, as the world faces its deepest recession since the Great Depression of the 1930s (Arnold, 2020).

Regarding the quality of the EU banks assets, they have improved significantly over the past 4 years. As of June 2019 , the weighted average loan loss ratio was $3 \%$, for example, in June 2015 - 6\%. This is the lowest indicator since the EBA introduced a harmonized definition of this indicator in all European countries in 2014. On average, it improves annually by 0.75 percentage points (European Banking Federation, 2019 a, p. 8).

The total volume of non-performing loans as of June 2019 amounted to 636 billion EUR, which is almost 50\% less than in June 2015. The decrease in non-performing loans can be explained by the sale and securitization of credit resources. Despite the fact that the quality of the loan portfolio is improving in all countries, this figure remains uneven in those with higher starting ratios (from less than 1\% in Sweden to 39\% in Greece).

Italy recorded the largest decrease in non-performing loans (145 billion EUR) between June 2015 and June 2019, as well as reductions in Spain ( 81 billion EUR), the United Kingdom (60 billion EUR) and Germany ( 43 billion EUR). All four countries recorded a reduction of at least $50 \%$. These countries are followed by Ireland (a decrease of 35 billion EUR or $80 \%$ ) and Portugal (a decrease of 20 billion EUR). Greek and Cypriot banks, which reported high ratios, reduced non-performing loans by 35 billion EUR $(-30 \%)$ and 17 billion EUR (-73\%), respectively (European Banking Federation, 2019 a, p. 15). 


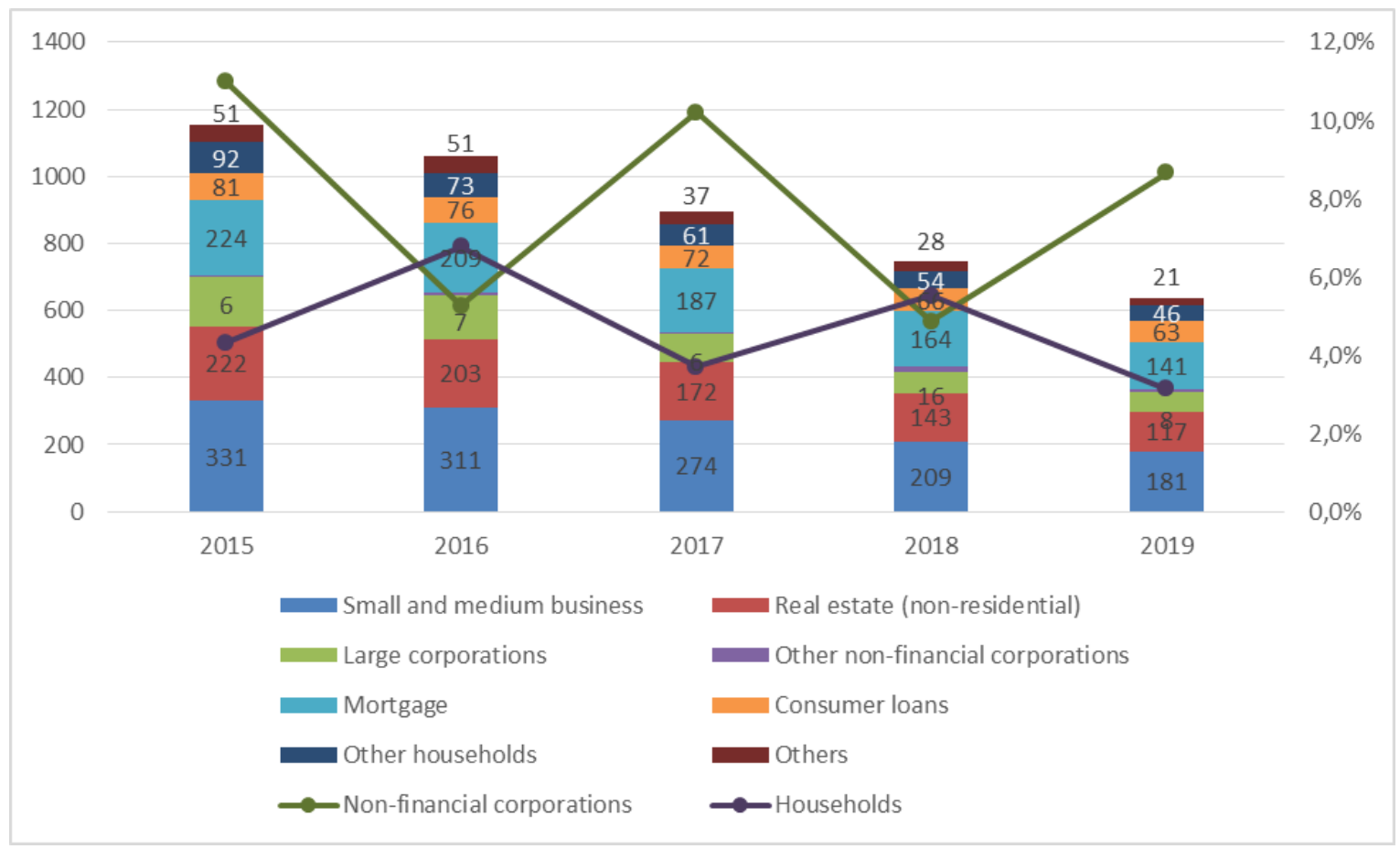

Figure 14. Total problem loans of the European banking sector, 2015-2019 billion EUR

Source: compiled by authors based on the European Central Bank, 2015-2019 (European Banking Federation, 2019 a)

This improvement in the quality of the loan portfolio was preceded by the following:

- efforts of banks to improve the management of non-performing loans, by improving monitoring and restructuring strategies, by investing in information technology and management;

- economic growth, lowering of unemployment level, low interest rates and dynamic development of the real estate market in the EU over the past 4 years. All these factors together increased the interest of investors.

In March 2018, the European Commission presented a package of measures to overcome the high rates of bad loans. The proposed measures are aimed at accelerating the progress already made in reducing the ratio and preventing its recovery. The package included (European Commission, 2019):

- a proposal for a resolution on amendments to the regulation of capital requirements and the introduction of general minimum levels of coverage for new loans that become bad. This measure will force banks to allocate funds to cover the risks associated with such problems;

- a proposal for a directive on those who service loans and their buyers, as well as on the procedure for collecting collateral. This measure will provide banks with an effective mechanism for out-of-court reimbursement of secured loans and will promote the development of secondary markets, in which banks can offer bad loans, and other specialized credit services to investors.
The Commission's working document on the drafting of National Asset Management Companies (AMCs) provides guidance to national authorities on how they can set up National Asset Management Companies (AMCs) to address bad loans.

Following the postponement of the national stress test to 2021, the Board of Supervisors agreed to conduct an additional transparency procedure to provide up-todate information on banking risks and the quality of market participants' assets.

Unlike stress tests, this procedure is a pure disclosure, where only data on each bank are published. The spring procedure of 2020 covers 127 banks from 27 countries of the European Economic Area, and the data are disclosed at the highest level of consolidation as of September 2019 and December 2019 (Moody's Analytics, 2020).

\section{Conclusion}

Thus, summarizing all the above-mentioned facts we can state that the number of credit institutions and their branches in the EU during the study period has a negative trend. At the same time, the total assets of the banking sector have a positive dynamic, and the expansion was mainly due to increased assets in the Eurozone. Similar to assets, the volume of bank liabilities also has a positive trend, increasing over the period under review by $41.2 \%$. Also encouraging is the fact that the quality of assets is improving every year, which indicates a balanced, wellstructured policy of banks and the Central Bank in general. 


\section{References:}

Ali, Z. (2020) Europe's 50 largest banks by assets, 2020. S\&P Global. Available at: https://www.spglobal.com/ marketintelligence/en/news-insights/latest-news-headlines/europe-s-50-largest-banks-by-assets-202057901087 (accessed 23 July 2020).

Altunbaş, Y., \& Chakravarty, S. (1998). Efficiency measures and the banking structure in Europe. Journal of Economics Letters, vol. 60(2), pp. 205-208.

Arnold, M. (2020). ECB data show eurozone banks had weak profits before coronavirus. Frankfurt. The Financial Times. Available at: https://www.ft.com/content/a1a62090-eb86-49e8-a326-dda868110d46 (accessed 23 July 2020).

Dermine, J. (2006). European Banking Integration: Don't Put the Cart before the Horse. Journal of Financial Markets, Institutions \& Instruments, vol. 15(2), pp. 57-106.

European Banking Authority (2019 a). EBA REPORT ON NPLs. Progress made and challenges ahead. Available at: https://eba.europa.eu/file/233465/download?token=xH5hxq39 (accessed 23 July 2020).

European Banking Authority (2019 b). 2019 NPL report statistical annex. Available at: https://cutt.ly/uhefzww (accessed 23 July 2020).

European Banking Federation (2019 c). Banking in Europe: EBF Facts \& Figures 2019. Available at: https://www.ebf.eu/wp-content/uploads/2020/01/EBF-Facts-and-Figures-2019-Banking-in-Europe.pdf (accessed 23 July 2020).

European Banking Federation (2019 d). Banking sector performance. Available at: https://www.ebf.eu/facts-andfigures/banking-sector-performance/ (accessed 23 July 2020).

European Central Bank (2020 a). Available at: https: / cutt.ly/thefbnl (accessed 23 July 2020).

European Central Bank (2020 b). Estimated MFI loans to NFCs by economic activity (NACE). Available at: https: / / cutt.ly/4hefnLZ (accessed 23 July 2020).

European central bank $(2020$ c). Financial corporations. List of financial institutions. Available at: https://cutt.ly/ihefQjz (accessed 23 July 2020).

European central bank (2020 d). Statistical data warehouse. MFI balance sheets Euro area lending, Households and non-profit institutions serving households. Available at: https: // cutt.ly/3hefTn2 (accessed 23 July 2020).

European central bank (2020 e). Statistical data warehouse. Money, credit and banking. Credit institutions and money market funds. Credit institutions. Assets. Available at: https://sdw.ecb.europa.eu/browse.do?node=9691315 (accessed 23 July 2020)

European central bank (2020 f). Statistical data warehouse. Money, credit and banking. Estimated MFI loans to NFCs by economic activity (NACE). Available at: https://cutt.ly/PhefUgN (accessed 23 July 2020).

European central bank (2020 g). Statistical data warehouse. Money, credit and banking. MFI aggregated balance sheet. Assets. Available at: https://sdw.ecb.europa.eu/browse.do?node=9691311 (accessed 23 July 2020).

European central bank $(2020$ h). Statistical data warehouse. Money, credit and banking. MFI balance sheets. Euro area. Loans by sector. Available at: https: / / cutt.ly/JhefIIu (accessed 23 July 2020).

European central bank (2020 i). Statistical data warehouse. Money, credit and banking. MFI aggregated balance sheet. Liabilities. Available at: https://sdw.ecb.europa.eu/browse.do?node=9691312/ (accessed 23 July 2020).

European central bank (2020 j). Statistical data warehouse. Publications Reports Money, credit and banking. MFI balance sheets. Euro area. Available at: https://sdw.ecb.europa.eu/browse.do?node=bbn3154 (accessed 23 July 2020).

European central bank $(2020 \mathrm{k})$. Statistical data warehouse. Publications. Reports. Money, credit and banking. MFI balance sheets. Euro area. Data. Available at: https:// cutt.ly/ehef2H5 (accessed 23 July 2020).

European central bank (2020 1). Statistical data warehouse. Supervisory and prudential statistics Macroprudential Database. Bank sector variables. Profitability. Available at: https://sdw.ecb.europa.eu/browse.do?node=9689369 (accessed 23 July 2020).

European central bank $(2020 \mathrm{~m})$. Supervisory and prudential statistics. Macroprudential Database. Bank sector variables. Banking structure. Available at: https://sdw.ecb.europa.eu/browse.do?node=9689367 (accessed 23 July 2020).

European Commission (2019). Non-performing loans (NPLs). EU and national authorities are joining forces to address the risks related to high stocks of NPLs in Europe. Available at:https://ec.europa.eu/info/business-economyeuro/banking-and-finance/financial-supervision-and-risk-management/managing-risks-banks-and-financialinstitutions/non-performing-loans-npls en (accessed 23 July 2020).

Goddard, J., Molyneux, P., Wilson, J., \& Tavakoli, M. (2007). European banking: An overview. Journal of Banking \& Finance, vol. 31(7), pp. 1911-1935.

Moody's Analytics (2020). EBA Releases Spring 2020. Transparency exercise data on banks in EU. Available at: https://www.moodysanalytics.com/regulatory-news/jun-08-20-eba-releases-spring-2020-transparency-exercisedata-on-banks-in-eu (accessed 23 July 2020).

Myshkin, F. (2008). Ekonomycheskaya teoryya deneg, bankovskogo dela ifynansovyx rynkov [The economic theory of money, banking and financial markets]. Moskva: OOO «Y.D. Vylyams». (in Russian)

Oesterreichische Nationalbank (2020). Consolidated balance sheet of euro area MFIs - liabilities. Available at: https://www.oenb.at/isaweb/report.do?report=1.4.3 (accessed 23 July 2020). 
Statistical data warehouse. European central bank Money, credit and banking MFI aggregated balance sheet Assets. Available at: https://sdw.ecb.europa.eu/browse.do?node=9691311 (accessed 23 July 2020).

Valverde, S., \& Fernández, F. (2018). Bank profitability ten years after the crisis: The digital opportunity. Funcas SEFO, vol. 7, no. 2, pp. 19-20. Available at: https://www.sefofuncas.com/pdf/Sefo_7-2_art03.pdf (accessed 23 July 2020). Veshkin, Yu. G., \& Avagyan, G. L. (2014). Bankovskaya systema Evrosoyuza:shest let kryzysa [The banking system of the European Union: six years of crisis]. Krasnodar Journal, vol. 39, no 615, pp. 46-43. Available at: https://cyberleninka.ru/article/n/bankovskaya-sistema-evrosoyuza-shest-let-krizisa (accessed 23 July 2020).

European Central Bank (2020 b). Estimated MFI loans to NFCs by economic activity (NACE). Available at: https://cutt.ly/AhefMEF (accessed 23 July 2020).

European central bank $(2020$ c). Financial corporations. List of financial institutions. Available at: https://cutt.ly/EhefB58 (accessed 23 July 2020).

European central bank (2020 d). Statistical data warehouse. MFI balance sheets Euro area lending, Households and non-profit institutions serving households. Available at: https://cutt.ly/AhefCZF (accessed 23 July 2020).

European central bank (2020 e). Statistical data warehouse. Money, credit and banking. Credit institutions and money market funds. Credit institutions. Assets. Available at: https://sdw.ecb.europa.eu/browse.do?node= 9691315 (accessed 23 July 2020)

European central bank (2020 f). Statistical data warehouse. Money, credit and banking. Estimated MFI loans to NFCs by economic activity (NACE). Available at: https://cutt.ly/WhefZIL (accessed 23 July 2020).

European central bank (2020 g). Statistical data warehouse. Money, credit and banking. MFI aggregated balance sheet. Assets. Available at: https://sdw.ecb.europa.eu/browse.do?node=9691311 (accessed 23 July 2020).

European central bank $(2020$ h). Statistical data warehouse. Money, credit and banking. MFI balance sheets. Euro area. Loans by sector. Available at: https: / / cutt.ly/dhefDrD (accessed 23 July 2020).

European central bank (2020 i). Statistical data warehouse. Money, credit and banking. MFI aggregated balance sheet. Liabilities. Available at: https://sdw.ecb.europa.eu/browse.do?node=9691312/ (accessed 23 July 2020).

European central bank (2020 j). Statistical data warehouse. Publications Reports Money, credit and banking. MFI balance sheets. Euro area. Available at: https://sdw.ecb.europa.eu/browse.do?node=bbn3154 (accessed 23 July 2020).

European central bank (2020 k). Statistical data warehouse. Publications. Reports. Money, credit and banking. MFI balance sheets. Euro area. Data. Available at: https://cutt.ly/KhefP4t (accessed 23 July 2020).

European central bank (2020 1). Statistical data warehouse. Supervisory and prudential statistics Macroprudential Database. Bank sector variables. Profitability. Available at: https://sdw.ecb.europa.eu/browse. do? node $=9689369($ accessed 23 July 2020)

European central bank $(2020 \mathrm{~m})$. Supervisory and prudential statistics. Macroprudential Database. Bank sector variables. Banking structure. Available at: https://sdw.ecb.europa.eu/browse.do?node=9689367 (accessed 23 July 2020).

European Commission (2019). Non-performing loans (NPLs). EU and national authorities are joining forces to address the risks related to high stocks of NPLs in Europe. Available at: https://ec.europa.eu/info/businesseconomy-euro/banking-and-finance/financial-supervision-and-risk-management/managing-risks-banks-andfinancial-institutions/non-performing-loans-npls_en (accessed 23 July 2020).

Goddard, J., Molyneux, P., Wilson, J., \& Tavakoli, M. (2007). European banking: An overview. Journal of Banking \& Finance, vol. 31(7), pp. 1911-1935.

Moody's Analytics (2020). EBA Releases Spring 2020. Transparency exercise data on banks in EU. Available at: https://www.moodysanalytics.com/regulatory-news/jun-08-20-eba-releases-spring-2020-transparency-exercisedata-on-banks-in-eu (accessed 23 July 2020).

Myshkin, F. (2008). Ekonomycheskaya teoryya deneg, bankovskogo dela i fynansovyx rynkov [The economic theory of money, banking and financial markets]. Moskva: OOO «Y.D. Vylyams». (in Russian)

Oesterreichische Nationalbank (2020). Consolidated balance sheet of euro area MFIs - liabilities. Available at: https://www.oenb.at/isaweb/report.do? report=1.4.3 (accessed 23 July 2020).

Statistical data warehouse. European central bank Money, credit and banking MFI aggregated balance sheet Assets. Available at: https://sdw.ecb.europa.eu/browse.do?node=9691311 (accessed 23 July 2020).

Valverde, S., \& Fernández, F. (2018). Bank profitability ten years after the crisis: The digital opportunity. Funcas SEFO, vol. 7, no. 2, pp. 19-20. Available at: https://www.sefofuncas.com/pdf/Sefo_7-2_art03.pdf (accessed 23 July 2020).

Veshkin, Yu. G., \& Avagyan, G. L. (2014). Bankovskaya systema Evrosoyuza:shest let kryzysa [The banking system of the European Union: six years of crisis]. Krasnodar Journal, vol. 39, no. 615, pp. 46-43. Available at: https://cyberleninka.ru/article/n/bankovskaya-sistema-evrosoyuza-shest-let-krizisa (accessed 23 July 2020 ). (in Russian) 